Volume 2 Number 2 March 2019

\title{
EFFECT OF ADDING POLYVINYL ACETATE AND COCONUT SHELL ON CONCRETE
}

\author{
Vivaldi Octavianto R. ${ }^{1}$, Fredy Kurniawan ${ }^{2}$, and Diah Ayu W.R. ${ }^{3}$ \\ Narotama University, Surabaya \\ valdi.octav@gmail.com
}

\begin{abstract}
Manufacture of concrete with a mixture of coconut shell and polyvinyl acetate. The material used in this study are from the coconut shell coconut waste treatment process which is crushed to a maximum size of $20 \mathrm{~mm}$, whereas polyvinyl acetate condition is milky white emulsion. This study uses laboratory experiments concrete according to standards ISO 7656: 2012 for normal concrete and developed into concrete innovation. Coconut shell as a substitute for gravel with a rate of $8 \%$ and $10 \%$, while the addition of polyvinyl acetate in the amount of $8 \%$ and $10 \%$. At the time of fresh concrete workmanship, testing the slump test to control the workability and homogeneity. Treatment (Curing) specimen is done by covering the paper specimens with wet cement. Compressive strength testing carried out during the 28 days of the test specimen. The results obtained on the compressive strength with the highest average percentage of materials such as concrete polyvinyl acetate $8 \%$ and $8 \%$ of coconut shell Amounting to $351 \mathrm{~kg} / \mathrm{cm}^{2}$ with an average density of $2199 \mathrm{~kg} / \mathrm{cm}^{3}$. In each of the test object with a weight value is the quality efficiency in concrete polyvinyl acetate $8 \%$ and $8 \%$ of coconut shell.
\end{abstract}

Keywords : Polyvinyl Acetat, Coconut Shell, Curing

\section{INTRODUCTION}

Concrete structure is one of the most jobs in the world. Basically, the concrete has a composition of cement, sand, aggregate, and water (Asroni, 2010). Nowadays, aggregates widely available at a price that is economical and has the quality of different, however, aggregate usage continuously in the long term, lead to the depletion of aggregate primary qualities and need a greater awareness of nature protection (Dahri and Syavir, 2013 ). In addition, the use of cement bound concrete jobs. In the industrial sector of cement, the cement manufacturing process which releases $\mathrm{CO}_{2}$ gas and energy needs will give effect to the presence of $\mathrm{CO}_{2}$ in the air (Malhotra, 1999). Carbon dioxide gas is a gas that can cause global warming.

Indonesia is a country with an area of $3,585,599$ ha of coconut plantations year (2015) with a value of production of 2,920,665 tons. The industrial sector, processed coconut on coconut fruit flesh alone and partly in the form of waste. One coconut palm waste is having a tough nature, light, absorb water, textured wood, it has a quality coconut shell as aggregates. 
polyvinyl acetateis an adhesive for porous materials, especially wood with adhesion (adhesivitas) high. Such materials are commercially creamy white or yellow saturated with emulsion and wet conditions. The use of inorganic or organic PVAC with concrete to make a higher density (Matsuri, 2010).

\section{RESEARCH METHODS}

Coconut shell processing as aggregates, namely, first clean the shell of coconut fibers, then wash and dry in the sun to dry. The latter process is pounding with the results of the size of $5-20 \mathrm{~mm}$.
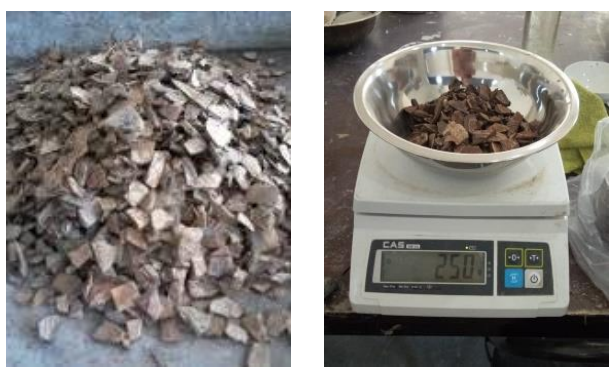

Figure 1. Coconut Shell For Aggregate

The materials used include the following, coconut shells that have been though, Polyvinyl acetate used is the brand of "Rajawali" a milky white with the conditions of the emulsion, sand originating from Lumajang, gravel with a size of $10 \mathrm{~mm}$ and drug concrete brand "ADDITON" type superplast.
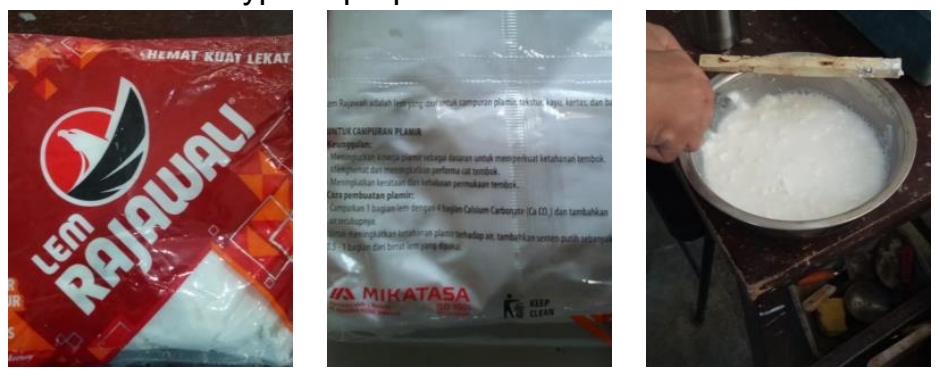

Figure 2. polyvinyl Acetat

Planning a material proportion of the concrete mixture using a mixture standarts election planning ISO 7656:2012 with the results as a reference for normal concrete is developed into concrete innovation.

Table 1. Objects Formula Test

\begin{tabular}{lccccccc}
\hline \multirow{2}{*}{ Test objects } & Cement & Sand & Gravel & $\begin{array}{c}\text { Coconut } \\
\text { shell }\end{array}$ & PVAC & Water & SP \\
\cline { 2 - 8 } & $(\mathrm{Kg})$ & $(\mathrm{Kg})$ & $(\mathrm{Kg})$ & $(\mathrm{Kg})$ & $(\mathrm{Kg})$ & $(I)$ & $(/)$ \\
\hline Normal & 380 & 1103 & 591 & - & - & 180 & 19 \\
CS PVAC 8\% + & 380 & 1103 & 544 & 47.28 & 30.4 & 180 & 19 \\
\hline
\end{tabular}


Volume 2 Number 2 March 2019

\begin{tabular}{lccccccc}
\hline $\begin{array}{l}8 \% \\
\text { PVAC } 8 \%+\text { CS }\end{array}$ & 380 & 1103 & 532 & 59.10 & 30.4 & 180 & 19 \\
$\begin{array}{l}10 \% \\
\text { CS PVAc 10\%+ }\end{array}$ & 380 & 1103 & 544 & 47.28 & 38.0 & 180 & 19 \\
$\begin{array}{l}8 \% \\
\text { CS PVAc 10\%+ }\end{array}$ & 380 & 1103 & 532 & 59.10 & 38.0 & 180 & 19 \\
$10 \%$
\end{tabular}

Preparation of test specimens made as many as 20 pieces in the shape of a cube, each made with five variations of the test specimen and four specimen at each variation. The test object in the form of a cube having a side of $15 \mathrm{~cm}$.

In the mixing stage, polyvinyl acetat dissolved into some of the water in the container, then soak the coconut in the container for 15 minutes to 30 minutes. At the time of stirring reserving some of the water, before the drug mixed concrete. After achieving a homogeneous fresh concrete, testing slump. In the maintenance phase of the test specimen, performed after a day old by covering the test object with cement soaked paper.

Compressive strength testing performed on the test specimen 28 days, after the drying process of care test object. Compressive strength testing conducted at the Laboratory of Civil Engineering Concrete Narotama University.

Quality relationship with a weight equal compressive strength (fc ') divided by density $\left(\mathrm{kg} / \mathrm{m}^{3}\right)$. The equation to determine an efficient compressive strength against weight. The more lightweight concrete with high compressive strength value then becomes the ideal value.

\section{RESULTS AND DISCUSSION}

Stage of the examination or test performed on the laboratory aggregate Concrete Civil Engineering Narotama Surabaya. Testing fine and coarse aggregates include moisture, density, volume weight, hygiene, sieving, as the following table;

Table 2. Aggregate testing

\begin{tabular}{lcc}
\hline \multicolumn{1}{c}{ This type of testing } & Smooth & Rude \\
\hline humidity sand & $1.7 \%$ & $0.5 \%$ \\
\cline { 2 - 3 } Bulk specific gravity & $2: 39$ & \\
Weight of saturated surface & $2: 48$ & $2: 35$ \\
dry & 2.60 & \\
$\begin{array}{l}\text { Apparent specific gravity } \\
\text { water absorption }\end{array}$ & $1: 24 \%$ & $7.76 \%$ \\
$\begin{array}{l}\text { Heavy volume (rojokan) } \\
\text { Cleanliness sludge }\end{array}$ & 1.81 & $1: 33$ \\
\cline { 2 - 3 } $\begin{array}{l}\text { (precipitation) } \\
\text { Cleanliness mud }\end{array}$ & $2.1 \%$ & \\
(laundering) & $4.2 \%$ & $5.5 \%$ \\
Fine grain Modulus & $3: 02$ & $2: 57$ \\
\hline
\end{tabular}


At the time of setting time, polyvinyl acetat has a long drying properties to the wet, while the SP (Superplast) is accelerating the hardening. At that time experienced a hard concrete surface but the conditions are not yet fully hard inside.

Concrete treatment processes (curing) by covering the test object with wet cement and paper soaked in water. Wood textured coconut shell that can absorb water, if soaked the coconut shells become obsolete and will decrease the compressive strength of the test specimen.

In testing the compressive strength, compressive strength is obtained as follows;

Table 3. Aggregate testing

\begin{tabular}{|c|c|c|c|c|}
\hline test specimen & $\begin{array}{l}\text { Specific } \\
\text { gravity }\end{array}$ & $\begin{array}{l}\text { compressive } \\
\text { strength } \\
\left(\mathrm{Kg} / \mathrm{cm}^{2}\right)\end{array}$ & $\begin{array}{l}\text { Specific } \\
\text { gravity } \\
\text { Average } \\
\left(\mathrm{Kg} / \mathrm{m}^{3}\right)\end{array}$ & $\begin{array}{c}\text { compressive } \\
\text { strength } \\
\text { Average } \\
\left(\mathrm{Kg} / \mathrm{cm}^{2}\right)\end{array}$ \\
\hline \multirow{4}{*}{ Normal } & 2008.9 & 144.44 & \multirow{4}{*}{2025} & \multirow{4}{*}{237} \\
\hline & 2009.5 & 266.67 & & \\
\hline & 2056.9 & 297.78 & & \\
\hline & 2023.4 & 240.00 & & \\
\hline \multirow{4}{*}{$\begin{array}{l}\text { CS PVAC } 8 \% \text { and } \\
8 \%\end{array}$} & 2168.0 & 293.33 & \multirow{4}{*}{2199} & \multirow{4}{*}{351} \\
\hline & 2211.6 & 333.33 & & \\
\hline & 2221.0 & 400.00 & & \\
\hline & 2196.7 & 377.78 & & \\
\hline \multirow{4}{*}{$\begin{array}{l}\text { PVAC } 8 \% \text { and } \\
10 \% \text { CS }\end{array}$} & 1973.6 & 253.33 & \multirow{4}{*}{2003} & \multirow{4}{*}{236} \\
\hline & 1979.0 & 242.22 & & \\
\hline & 2025.5 & 235.56 & & \\
\hline & 2032.9 & 213.33 & & \\
\hline \multirow{4}{*}{$\begin{array}{l}\text { CS PVAc } 10 \% \text { and } \\
8 \%\end{array}$} & 2138.4 & 273.33 & \multirow{4}{*}{2143} & \multirow{4}{*}{288} \\
\hline & 2213.0 & 311.11 & & \\
\hline & 2069.0 & 26667 & & \\
\hline & 2151.4 & 300.00 & & \\
\hline \multirow{4}{*}{$\begin{array}{l}\text { CS PVAc } 10 \% \text { and } \\
10 \%\end{array}$} & 2048.0 & 222.22 & \multirow{4}{*}{2113} & \multirow{4}{*}{267} \\
\hline & 2109.0 & 297.78 & & \\
\hline & 2113.2 & 231.11 & & \\
\hline & 2182.8 & 315.56 & & \\
\hline
\end{tabular}

The influence of the addition of coconut shells in concrete, can be seen in the following chart; 
Figure 3. Compressive Strength Test Objects

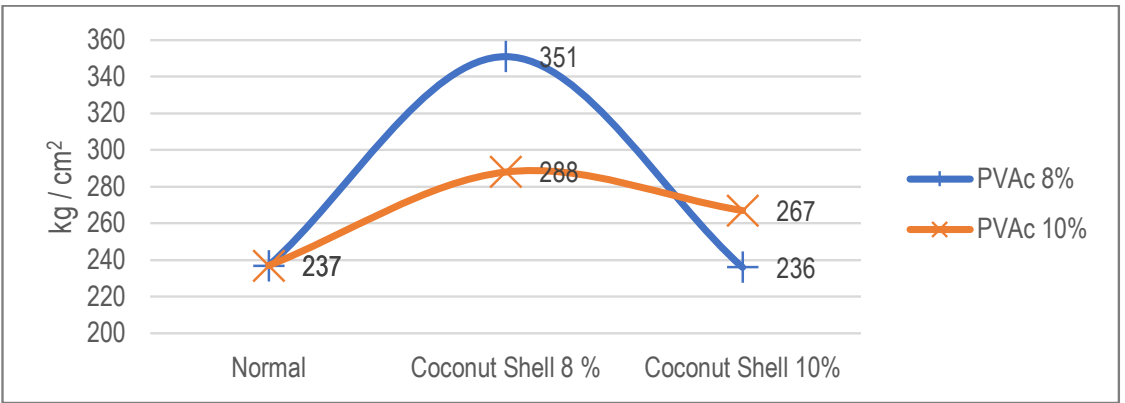

A normal concrete compressive strength is an average of $237 \mathrm{~kg} / \mathrm{cm}^{2}$. Test specimen polyvinyl acetate and coconut with a proportion of $8 \%$ and $8 \%$ have a compressive strength of $351 \mathrm{~kg} / \mathrm{cm}^{2}$, the addition of $10 \%$ polyvinyl acetate and the result has decreased by $236 \mathrm{~kg} / \mathrm{cm}^{2}$. While the specimen at a proportion of $10 \%$ polyvinyl acetate and $8 \%$ coconut has a compressive strength of $288 \mathrm{~kg} / \mathrm{cm}^{2}$, the addition of $10 \%$ polyvinyl acetate and the result is decreased by $267 \mathrm{~kg} / \mathrm{cm}^{2}$. If the note is the addition of coconut decreased compressive strength

Table 4. Relationship Quality and Density

\begin{tabular}{lccc}
\hline \multicolumn{1}{c}{ Test objects } & $\begin{array}{c}\text { Compressive } \\
\text { Strength } \\
(\mathrm{Fc})\end{array}$ & $\begin{array}{c}\text { Specific } \\
\text { gravity } \\
\left(\mathrm{Kg} / \mathrm{m}^{3}\right)\end{array}$ & $\begin{array}{c}\text { Compressive } \\
\text { strength / density } \\
(\mathrm{Fc}) /\left(\mathrm{kg} / \mathrm{m}^{3}\right)\end{array}$ \\
\hline Normal & 237 & 2025 & 0117 \\
PVAC $8 \%+$ CS $8 \%$ & 351 & 2199 & 0159 \\
PVAC $8 \%+$ CS $10 \%$ & 236 & 2003 & 0118 \\
PVAc 10\%+CS 8\% & 288 & 2143 & 0134 \\
PVAc 10\%+CS & 267 & 2113 & 0126 \\
$10 \%$ & &
\end{tabular}

In Table 4, obtained the value of quality efficiency with a specific gravity that is in material polyvinyl acetate $8 \%$ and $8 \%$ coconut shells with an average compressive strength of $351 \mathrm{~kg} / \mathrm{cm}^{2}$ and a density of $2199 \mathrm{~kg} / \mathrm{m}^{3}$.

\section{CONCLUSION}

On the results of research and discussion that has been done can be some conclusions as follows:

1. Influence of the concrete to the addition of coconut shells are heavy concrete may be light, but the addition of coconut shell by $10 \%$ decreased the compressive strength compared to the addition of coconut shells at $8 \%$ with the compressive strength of $236 \mathrm{~kg} / \mathrm{cm}^{2}$ of $351 \mathrm{~kg} / \mathrm{cm}^{2}$ and $267 \mathrm{~kg} / \mathrm{cm}^{2}$ of $288 \mathrm{~kg} / \mathrm{cm}^{2}$. Meanwhile, the effect of the addition of polyvinyl acetate as the added material that can bind coconut shells with concrete because the adhesion properties of polyvinyl 
Volume 2 Number 2 March 2019

acetate, but at the time of setting time, the influence of polyvinyl acetate which makes the concrete hardens longer than normal concrete.

2. In this study, the planned compressive strength is equal to $200 \mathrm{~kg} / \mathrm{cm}^{2}$ with a safety factor of $250 \mathrm{~kg} / \mathrm{cm}^{2}$. On the results obtained value of the compressive strength of the average on the test object with the proportion of ingredients, among others, specimen concrete polyvinyl acetate $8 \%$, coconut shell $8 \%$ achieved compressive strength of $351 \mathrm{~kg} / \mathrm{cm}^{2}$, the test specimen concrete polyvinyl acetate $8 \%$, coconut shell $10 \%$ achieved compressive strength of $236 \mathrm{~kg} / \mathrm{cm}^{2}$, while the test specimen concrete polyvinyl acetate $10 \%$, coconut shell $8 \%$ achieved compressive strength of $288 \mathrm{~kg} / \mathrm{cm}^{2}$, and the test specimen concrete polyvinyl acetate $8 \%$, coconut shell $10 \%$ achieve strong press at $267 \mathrm{~kg} / \mathrm{cm}^{2}$.

3. The optimum mix design in terms of density and compressive strength of the concrete specimen is at $8 \%$ polyvinyl acetate, coconut shell $8 \%$ with average density of $2199 \mathrm{~kg} / \mathrm{m} 3$ and a compressive strength of $351 \mathrm{~kg} / \mathrm{cm}^{2}$.

\section{ACKNOWLEDGMENTS}

In order to produce research which will be better in the authors suggest further research attention to the following:

1. In the early stages of preparation of materials, especially coarse and fine aggregate, aggregate that has been washed and was in a state of SSD, should be placed in a genuinely can retain up to an aggregate SSD condition ready for use.

2. In order to get the proper mixing there should be further studies on the properties of the concrete example of trial and error.

3. It should be noted at levels of added water if using a material such as superplast, accident on the water level is high enough.

\section{REFERENCES}

Ajay dan Susheel, (2017). Effect of Coconut Husk on the Properties of Concrete. International Journal for Scientific Research and Development

Asroni. Ali, 2010. Balok dan Pelat Beton Bertulang. Yogyakarta, Graha ilmu.

Dahri dan Syavir, 2013. Kuat Tekan Beton Daur Ulang sebagai Bahan Struktur pada Bangunan Sederhana. Prosiding Temu IImiah IPLBI.

Ida Sriyanti dan Leni Marlina, 2014. Pengaruh Polyvinyl Acetate (PVAc) terhadap Kuat Tekan Material Nanokomposit dari Tandan Kelapa Sawit. Jurnal Inovasi dan Pembelajaran Fisika.

Malhotra, 1999. Making Concrete "Greener" With Fly Ash. ACI Concrete International.

Matsuri, dkk. 2010. Efektivitas Polyvinyl Acetate (PVAc) sebagai Matriks pada Komposit Sampah. Berkala Fisika.

Mudjanarko, dkk, 2018. Optimization of Standard Mix Design of Porous Paving Coconut Fiber and Shell for the Parking Area. Advances in Civil Engineering and Science Technology, American Institute of Physics. 
Volume 2 Number 2 March 2019

Standar Nasional Indonesia, 2012. Tata Cara Pemilihan Campuran untuk Beton Normal, Beton Berat dan Beton Massa dengan Standar SNI 7656:2012. Jakarta, Badan Standarisasi Nasional. 